\title{
The Free City of Kraków in the Regional Security Policies of its Neigbbouring States
}

\begin{abstract}
The aim of this article is to present the status of the Free City of Kraków in the policies of its neighbouring states, i.e. Austria, Prussia, and Russia, in regards to regional security (in areas of Central and Eastern Europe under the legal or real sovereignty of these powers). The main objective of the regional policy conducted by these powers was to protect the status quo and maintain the ancien régime in their respective states, along with upholding security and public order in the region. The article draws attention to the main ideas underlying the cooperation of these counties in this respect, and identifies the conventions and secret agreements that had direct impact on the creation, functioning, and dismantling of the Republic of Kraków. It further discusses the roles of the representatives of the protecting powers in Kraków, and their influence on the activity and reorganization of the city's administration, police, militia, and judiciary. It offers examples that illustrate the consequences that the inhabitants of the Free City of Kraków suffered due to the legal and factual dependence of the state on the policies of the partitioning powers.
\end{abstract}

Keywords: Free City of Krakow, administration, judiciary, police, order and public security, regional security

Słowa kluczowe: Wolne Miasto Kraków, administracja, sądownictwo, policja, porządek i bezpieczeństwo publiczne, bezpieczeństwo regionalne

More than two centuries ago, at the Vienna Congress in 1815, the countries of the Holy Alliance decided on the fate of post-Napoleonic Europe and on the next division of the Polish lands (the so-called fourth partition of Poland). One of the points of disagreement between the powers was control of Kraków. Although the city had declined in the later years of the Polish-Lithuanian Commonwealth and in the uncertain times of the Duchy of Warsaw, it was still of great value. It was a potential centre for trade, industrial production and a strategic transport hub, therefore Austria, Russia and Prussia were all equally interested in taking possession of the former capital of Poland. Eventually, their particular interests gave way to a political compromise, which resulted in the establish- 
ment on 3 May 1815 of the Free, Independent and Strictly Neutral City of Kraków and its Territory [Wolne, Niepodległe i Ściśle Neutralne Miasto Kraków wraz z Okręgiem], under the joint control of these powers. ${ }^{1}$

This miniature enclave, including Kraków and the lands on the left bank of the Vistula, had an unusual system in an era of sovereign absolutism. It was a republic, and therefore was called the Free City of Kraków [Wolne Miasto Kraków] or the Republic of Kraków [Rzeczpospolita Krakowska]. ${ }^{2}$ It bordered directly on the Kingdom of Prussia, the Austrian Empire and the Kingdom of Poland, which was in personal union with the Russian Empire. The neighbouring countries were quintessential dynastic and absolute states, which did not augur well for the existence and independence of the Free City of Kraków. A certain exception, of course, was the Kingdom of Poland, which, although it had a liberal constitution (granted by Tsar Alexander I), in fact remained under the rule of the absolute tsar of Russia, who after just a few years, began to limit gradually the sovereignty and independence of the autonomous Kingdom from Russia. ${ }^{3}$

Thus, the neighbouring states, namely Austria, Prussia and de facto Russia, as partitioning and at the same time as protecting states (acting in this role under an additional treaty signed at the Vienna Congress), were to guarantee the eternal and strict neutrality of the Free City of Kraków. One can see in this an attempt to implement the idea of the Congress of Vienna, i.e. the joint responsibility of the great powers for the stabilisation of international relations, for the maintenance of international peace and security in Europe, and for the struggle against dangerous ideologies disturbing the peace (the Metternich system). These ideas also became the basis for the cooperation of the protecting states as well as allied actions regarding the Kraków republic. This cooperation was also necessary for the maintenance of political stability in these countries, as well as security and public order in the region. Therefore, the main objective of the regional policy conducted by Austria, Prussia and Russia was to protect the status quo and maintain the ancien régime in their respective states. ${ }^{4}$ These powers wanted to and did indeed play their role as guardians of regional security and simultaneously their own vital interests. ${ }^{5}$

${ }^{1}$ S. Wachholz, Rzeczpospolita Krakowska. Okres od 1815 do 1830 r. [The Republic of Kraków: 18151830], Warszawa 1957, pp. 33-34; W.M. Bartel, Ustrój i prawo Wolnego Miasta Krakowa (1815-1846) [The system and the law in the Free City of Kraków (1815-1846)], Kraków 1976 [Biblioteka Krakowska, no. 116], pp. 7-8; P. Cichoń, Kongres wiedeński a sprawa polska [The Congress of Vienna and the Polish Question] [in:] Idee, normy i instytucje kongresu wiedeńskiego - 200 lat później - perspektywa prawnomiędzynarodowa [Ideas, norms and institutions of the Congress of Vienna - 200 years later - an international legal perspective], eds. J. Menkes et al., Warszawa 2016, pp. 21-22; M.J. Nadziak, Nostalgia za ancien regime'em. Filary europejskiego pokoju 1815-1914 [Nostalgia for the ancien régime: The keystone of European peace], Warszawa 2016, p. 111.

2 A. Wedel-Domaradzka, Wolne miasta w prawie międzynarodowym [Free cities in international law] [in:] Idee, normy i instytucje kongresu wiedeńskiego - 200 lat później - perspektywa prawnomiędzynarodowa [Ideas, norms and institutions of the Congress of Vienna - 200 years later - an international legal perspective], eds. J. Menkes et al., Warszawa 2016, pp. 454-455.

${ }^{3}$ S. Kieniewicz, Polacy wobec traktatu wiedeńskiego [Poles and the Treaty of Vienna] [in:] Europa $i$ świat w epoce restauracji, romantyzmu i rewolucji, 1815-1849 [Europe and the world in the era of restoration, Romanticism and revolution, 1815-1849], ed. W. Zajewski, Warszawa 1991, pp. 67-68.

${ }^{4}$ B. Jelavich, The Habsburg Empire in European Affairs 1814-1918, Hamden, CT 1975, pp. 25, 27, 28; M.J. Nadziak, Nostalgia ..., pp. 64-65.

${ }^{5}$ S.M. Judson, Imperium Habsburgów. Wspólnota narodów [The Habsburg Empire: A community of nations], thum. S. Patlewicz, Warszawa 2017, pp. 134-137; M.J. Nadziak, Nostalgia..., pp. 124-129.

Artykuły - Articles 
The allied actions they undertook in regard to the authorities of the Free City of Kraków, as well as in regard to their decisions, were often supported by occupying military forces, which guaranteed the submission and servitude of the local authorities to the political decisions of the invaders. ${ }^{6}$

This approach by the leaders of the protecting powers to the Free City of Kraków was also based on the unanimous assumption that the existence of this state was temporary and that it would be abolished in due course as a rather exotic political entity in Europe. ${ }^{7}$

At this point, it should be noted that the Poles had a completely different perception of the creation of the Free City of Kraków. Gradually, the conviction of Kraków's exceptionality grew, which stirred the patriotic sentiments of the inhabitants of this city. For them, despite everything, it was the last free shred of the Republic of Poland. The Kingdom of Poland, including Warsaw, remained under the rule of one of the partitioning powers. In the Free City of Kraków, executive power was held by the Governing Senate [Senat Rządzący] headed by its president, while legislative power and control were exercised by the Assembly of Representatives [Zgromadzenie Reprezentantów] - bodies that in theory were independent, yet which in practice were subject to various pressures, even chicanery, from the representatives of three protecting powers. Kraków became the heart of Poland in the common consciousness of Poles. In the face of the tragedy of the partitions of Poland, like no other city, it was associated with the power and glory of the capital of the Piast and Jagiellonian state. And it was precisely the clash of pragmatic plans of the protecting powers with the awakened hopes for the historical role of Kraków as a liberator from the domination of partition that led to a deadly confrontation in $1846 .{ }^{8}$

There are many examples that confirm the domineering influence of the protecting powers over the Free City of Kraków. Due to the scope of the this work, only the most important will be discussed here, which have already been described in the literature in Polish, which show how Austria, Prussia and Russia - euphemistically speaking "protected" of the Kraków republic, thus implementing a shared concept of maintaining internal order in that state and controlling the situation in the region. These examples are presented taking into account both their chronology and content.

First of all, it should be emphasized that the political and legal status of the Free City of Kraków was directly determined by the common arrangements of the rulers of the protecting states, which took the form of international conventions or secret agreements. An additional treaty signed on 3 May 1815, by the representatives of Austria,

${ }^{6}$ Until December 1815, there was a Russian Garrison in Kraków. M. Baczkowski, W cieniu napoleonskich ortów. Rada Municypalna Krakowa 1810-1815 [In the shadow of the Napoleonic eagles: The Municipal Council of Kraków, 1810-1815], Kraków 2010, p. 106. On 27 November 1831, the three-month Russian occupation under the command of General T. Rüdiger began. From 17 February 1836 to 20 February 1841, Kraków was occupied by Austrian, Prussian, and Russian forces. On 18 February 1846, the Austrian army returned to Kraków, in preparation to repel an advance by the uprising that had broken out a few days before. P. Cichoń, Dyrekcja Policji Wolnego Miasta Krakowa 1827-1846. Studium historyczno-prawne [The Police Directorate of the Free City of Cracow (1827-1846). A Historical and Legal Study], Kraków 2014, pp. 23, 92; W.M. Bartel, Ustrój ..., p. 14.

${ }^{7}$ A. Wedel-Domaradzka, Wolne miasta ..., p. 455; W. Pęksa, Poglady na temat statusu prawno-międzynarodowego Wolnego Miasta Krakowa [Views on the international legal status of the Free city of Kraków], "Krakowskie Studia z Historii Państwa i Prawa" 2008, Vol. 2, s. 195-206.

${ }^{8}$ W.M. Bartel, Ustrój ..., p. 15. 
Prussia and Russia, under which it was agreed to establish the Free City of Kraków, was of state-forming importance for this republic. Article 2 of this treaty also defined the territorial boundaries of the future republic. ${ }^{9}$ This treaty was recognised as an integral part of the Final (General) Act signed in Vienna on 9 June 1815 by England, Austria, France, Prussia, Prussia and Russia. ${ }^{10}$

The political framework of the new state was defined in the constitutions, which were jointly granted by the monarchs of Austria, Prussia and Russia. In the short period of its existence, only 31 years (1815-1846), the Free City of Kraków had as many as three constitutions. The first, that of 3 May 1815, ${ }^{11}$ was already issued in Vienna and appended to the peace treaty of the same day. It also became a part of the final resolutions of the Congress of Vienna. The final text of the Constitution of 11 September $1818^{12}$ was prepared by the Organising Commission [Komisja Organizacyjna]. The text of the Constitution of 30 May $1833^{13}$ was prepared by the Reorganisation Commission [Komisja Reogranizacyjna] in accordance with recommendations from Vienna. The participation of local authorities in the work on these constitutions was insignificant. ${ }^{14}$

All three constitutions guaranteed the preponderance of the executive over the legislature, making it much easier for the protecting countries (also unofficially) to influence the activities and decisions of local authorities. This corresponded closely with the personnel policy of these countries regarding the staffing of key public positions in the Kraków republic.

In the 1830 s, diplomatic action was taken to lay the foundations for the future dissolution of the Republic of Kraków. During the Münchengrätz Conference in 1833, the rulers of Russia and Austria declared joint actions, based on the principle of solidarity, aimed at eliminating all revolutionary dangers in Europe ${ }^{15}$ as well as maintaining legitimate power, peace and legality of the order in the Free City of Kraków. The monarchs, referring to Article 9 of the supplemental treaty of 3 May 1815 ensuring the strict neutrality of the Republic of Kraków, stated that "they have the right to ensure that, for the sake of this neutrality, nothing is done there that may disturb the order of things, only

9 J. Bieniarzówna, Rzeczpospolita Krakowska 1815-1846. Wybór źródet [The Republic of Kraków, 1815-1846: Selected sources], seria „Skarby Biblioteki Narodowej”, Wrocław-Warszawa 2004, p. 8; J. Bieniarzówna, J.M. Małecki, Kraków w latach 1796-1918 [Kraków 1796-1918], seria „Dzieje Krakowa”, Vol. 3, Kraków 1979, p. 39; M. Kallas, M. Krzymkowski, Historia ustroju i prawa w Polsce 1772/1795-1918. Wybór źródet [History of the legal system in Poland 1772/1795-1918: Selected sources], Warszawa 2006, pp. 174-178.

10 S. Wachholz, Rzeczpospolita..., p. 34; W.M. Bartel, Ustrój..., p. 8.

11 M. Kallas, M. Krzymkowski, Historia ..., pp. 179-182.

12 Ibidem, pp. 183-190.

13 Ibidem, pp. 190-201.

14 W.M. Bartel, Ustrój..., pp. 16, 42.

15 M. Sedivy, Metternich, the great Powers and the Eastern Question, Pilsen 2013, p. 538; M. Chvojka, Josef Graf Sedlnitzky als Präsident der Polizei- und Zensurhofstelle in Wien (1817-1848). Ein Beitrag zur Geschichte der Staatspolizei in der Habsburgermonarchie [Josef Graf Sedlnitzky as President of the Court Police and Censorship Office in Vienna (1817-1848): A contribution to the history of the state police in the Habsburg Monarchy], Frankfurt am Main-New York 2010, series "Schriftenreihe der Internationalen Forschungsstelle «Demokratische Bewegungen in Mitteleuropa 1770-1850»" [Series of the "Democratic Movements in Central Europe 1770-1850" international research centre], Vol. 42, pp. 306-311.

Artykuły - Articles 
restored in this Free City under the aegis of the three powers, or would threaten security and peace in neighbouring countries." They therefore declared that:

$[\ldots]$ any public or secret act having such a purpose or any participation in such an act must be considered a violation of the neutrality of Cracow; and if the government of the Free City, in response to the petitions and complaints directed toward it, should not be inclined to suppress the conspiracies brought to its attention or not have the means to apprehend the perpetrators, the high contracting parties reserve the right to immediately establish military occupation of the Free City of Cracow and its Territory. This occupation will be carried out, depending on the cause, either by the armies of all three powers, or by an adequate detachment of one of them, but always in the name of the Three Protecting Courts. They reserve the right, as the case may be, to agree on the duration of such temporary occupation and to take measures to prevent the return of the relations which were its cause. ${ }^{16}$

The Münchengrätz agreement was also signed by Prussia. A few years later, at the Congress of Cieplice (Töplitz) in 1835, the monarchs stated that: "the existence of the Republic of Cracow is as much opposed to the material interests of its inhabitants as to the prosperity of the country in general, and is also harmful to the security of neighbouring countries." Therefore, it was concluded that: "the sole means to prevent these inconveniences caused by the present state of affairs in both respects is the incorporation of Cracow and its territory into the lands of one of the Three Powers." There was also a desire to increase control over the Free City of Kraków by strengthening its economic ties with Austria. It was also agreed that the Vienna Government would develop a way of gradually implementing the provisions of this treaty, which would also be communicated to the inhabitants of Kraków. These arrangements were subsequently confirmed by the agreement signed in Berlin on 14 October 1835 between the protecting powers. ${ }^{17}$

The political consensus regarding the dissolution of the Free City of Kraków had its finale in the convention concluded in Vienna on 6 November 1846 between the monarchs of the protecting states on the cancellation and revocation of the treaties concluded on 3 May 1815 with regard to the city of Kraków. On the basis of this convention, Austrian Emperor Ferdinand I issued an act on 11 November 1846 taking possession of the city of Kraków and its territory. It was indicated in this act that the Free City had not fulfilled its obligations concerning, among other things, the maintenance of strict neutrality as well as the expulsion of fugitives who were subjects of Austria, Prussia or Russia. The emperor's patent also indicated that restoration of the foundations of the freedom and independence of Kraków was impossible, and at the same time the need to protect neighbouring countries from the spectre of revolution. ${ }^{18}$

Another issue deserving of attention in the context of the issue in question is that the protecting powers, with the idea of the perpetual neutrality of the Free City of Kraków, deprived it of the ability to conduct its own foreign policy. In fact, it was a non-sovereign state, regarded with great distrust. Its only diplomatic representative was at the court in Vienna, and that only until $1831 .{ }^{19}$ Direct control over the activities of the authorities of

16 J. Bieniarzówna, Rzeczpospolita..., pp. 315-316.

17 W.M. Bartel, Ustrój..., pp. 15-16.

18 M. Kallas, M. Krzymkowski, Historia ..., pp. 178-179.

19 L. Królikowski (pseud. H. Meciszewski), Memoriat historyczny i polityczny o stanie obecnym Wolnego Miasta Krakowa i jego okregu na poparcie adressu obywateli krakowskich podanego rzadowi francuzkiemu i angielskiemu w październiku 1839 roku z dołączeniem zbioru dokumentów [Historical and political memoir 
the Free City of Kraków was exercised by diplomatic representatives appointed by the protecting powers, called Residents, who were stationed permanently in Kraków. They were also part of the bodies appointed by these states, which were entrusted with defining the political principles, organisational structure and competences of the local authorities (the Organising Commission, 1815-1818, and then the Reorganisation Commission, 1833-1836). ${ }^{20}$ These entities were fully independent of the authorities of the Free City of Kraków.

The diplomatic representatives of Austria, Prussia and Russia also exercised direct supervision over the preservation of the established legal order of the Republic of Kraków. Until the beginning of the 1830 s, their interference in the internal affairs of the state was more incidental and involved arbitration and control activities undertaken as a result of the intervention of the President of the Senate, Stanisław Wodzicki. ${ }^{21}$ The informal activity of the Residents resulted from the fact that neither the Constitution of 1815 nor the Constitution of 1818 granted them any powers, including suzerain rights over the authorities of the Free City of Kraków. ${ }^{22}$ The influence of the Residents can be seen very clearly in 1827 , when they intervened in the matter of attempts to change the president of the senate democratically. ${ }^{23}$ They also had a significant hand in influencing the Senate to introduce changes in 1821 to the organisation and regulations of the Jagiellonian University to limit its broad autonomy. ${ }^{24}$ However, it was not until the Constitution of 1833 that the Residents were formally granted the right to act as superiors to the authorities of the Free City. As a result, in the next decade the activity of the Residents in the internal reforms of the Free City of Kraków grew much more intense. They also played the role of mediators in matters between the Governing Senate and

of the present state of the Free City of Kraków and in support of the address of Kraków citizens submitted to the French and English governments in October 1839, with an appendix of a collection of documents], Paris 1840, p. 68; W. M. Bartel, Ustrój..., p. 43.

${ }^{20}$ K. Bąkowski, Historya Krakowa w zarysie [Outline of the History of Kraków], seria „Biblioteka Krakowska”, no. 6, Kraków 1916, p. 181. The proposal to form a Conference of Residents was submitted by Chancellor Klemens von Metternich on 21 November 1831. J. Bieniarzówna, J. M. Małecki, Kraków..., p. 80.

${ }^{21}$ Direct intervention by the protecting states was very rare, e.g. in 1818 Tsar Alexander I intervened on the budget, Austrian Chancellor Metternich intervened regarding the University. S. Wachholz, Rzeczpospolita..., p. 192.

${ }_{22}$ Ibidem, pp. 39, 208-216; W.M. Bartel, Ustrój..., pp. 44-45; O. Beiersdorf, Kraków wobec powstania listopadowego [Kraków and the November Uprising], Katowice-Kraków 1981, pp. 214-215.

${ }^{23}$ The residents did not recognize the election (by one vote) of the opposition candidate, Józef Nikorowicz, and ordered Stanisław Wodzicki to continue to hold the office of the President of the Senate (who had held this office since 1815). At the same time, opposition-minded senators, judges, officials and professors were removed. Following news of the outbreak of the November Uprising, the residents supported the reinstatement of those removed. Next, street demonstrations in favour of the uprising forced the resignation of President of the Senate Wodzicki on 18 January 1831, after which the office remained vacant for three years. The duties of president were executed on a rotating basis by members of the Governing Senate, changing every month. B. Winiarski, Ustrój polityczny ziem polskich w XIX wieku [The political system in Polish lands in the nineteenth century], Poznań 1923, pp. 198-199; S. Wachholz, Rzeczpospolita ..., pp. 224-237; W.M. Bartel, Ustrój..., p. 46; J. Bieniarzówna, J.M. Małecki, Kraków..., p. 44; J.M. Małecki, Historia Krakowa dla każdego [A history of Kraków for everyone], Kraków 2008, pp. 174-185.

${ }^{24}$ B. Winiarski, Ustrój..., p. 198; S. Wachholz, Rzeczpospolita ..., pp. 193-198; W.M. Bartel, Ustrój..., p. 46; L. Ręgorowicz, Szkolnictwo W. M. Krakowa w dobie kuratorji Józefa hr. Zaluskiego [Education in the Free City of Kraków at the time of the superintendency of Count Józef Załuski], Warszawa 1930, pp. 27-30.

Artykuły - Articles 
the Assembly of Representatives (or within each of these institutions separately) in the interpretation of constitutional regulations and in disputes over competences.

Starting in 1833, the Residents were already acting as the Conference of Residents, which in 1839 was transformed into the permanent "Continual Conference for the Land of Kraków" ${ }^{25}$ Thus, the Conference became an external body whose approval was required for the work of the entire state apparatus of the Free City of Kraków. In 1837, the Residents also received the right to communicate with the president of the senate on matters concerning local order and security, which had been reported by the director of the police or the commander of the militia. ${ }^{26}$

As of 1842, the Residents also had an influence on the composition of the Kraków Parliament, as it was up to them to accept who was to receive the mandate of a representative. Starting in 1845 , Residents could also settle disputes over competences between administrative and judicial authorities. ${ }^{27}$

An effective policy of interference in the internal affairs of the Free City of Kraków in order to maintain the status quo there also required a direct influence on the who occupied Kraków's state authorities. This was probably the most important instrument which gave a real opportunity to influence the affairs of the Free City and to subordinate them to the regional policy of the protecting powers.

The Organising Commission appointed the first members of the Governing Senate, including the president, and it also named judges, in violation of the constitution. ${ }^{28}$ In 1818-1824, the president of the senate was elected by the Assembly of Representatives, but with the consent of the protecting courts. Starting in 1827, after Józef Nikorowicz's election was invalidated, ${ }^{29}$ all subsequent presidents were appointed, not elected. ${ }^{30}$ After 1837, the Residents also had the right to strike candidates from the list of Senate members, which in practice meant gaining direct influence over the composition of the government. After 1843, the protecting states were granted the exclusive right to appoint the president of the senate as well as all senators. In addition, the Residents were granted the right to freely remove persons from these positions. ${ }^{31}$ Thus, near the end of the Free City of Kraków, the Governing Senate became de facto the arm of the Conference of Residents. It also had an impact on the number of judges and court presidents, and only Austrian, Prussian or Russian judges could become president of the highest criminal court. ${ }^{32}$

In 1836, the protecting powers directly imposed Austrian candidates for the positions of commandant of the militia (Major Joseph Holfeld) and director of the police (police commissioner Franz Guth) on the authorities of the Free City of Kraków. ${ }^{33}$ From that

${ }^{25}$ W.M. Bartel, Ustrój..., p. 46.

${ }^{26}$ Dz. Praw [Journal of Laws] 1837, no. 5436 D.G.S.; P. Cichoń, Kongres..., p. 104.

27 Dz. Praw [Journal of Laws] 1845, no. 5087 D.G.S.

${ }^{28}$ W.M. Bartel, Ustrój..., p. 86.

${ }^{29}$ S. Wachholz, Rzeczpospolita ..., pp. 224-237.

${ }^{30}$ W.M. Bartel, Ustrój..., p. 49; J. Bieniarzówna, J.M. Małecki, Kraków..., p. 80.

31 Dz. Praw [Journal of Laws] 1843, nr 6 D.G.S.

32 W.M. Bartel, Ustrój..., p. 122.

${ }^{33}$ The Residents informed the Governing Senate that the intervention of the protecting powers was made with "the good of the country here in mind", and also wishing to hasten the moment of departure from "this country of the troops of the country occupying it”. B. Winiarski, Ustrój ..., p. 204. 
time on, these positions were entrusted only to Austrian officials on the initiative and with the consent of the protecting states. ${ }^{34}$ In addition, candidates for the police and militia were required to have a "clean record" of their past, i.e. no connections with secret organizations, nor participation in the November Uprising of 1830/1831, or later in the Kraków Uprising of 1846.

The ideological considerations indicated in the introduction had a particular impact on the perception by Austria, Prussia and Russia of questions of order and security in the Free City of Kraków. This was connected, among other things, with the absolute enforcement by these countries of compliance with Article 6 of the supplemental treaty, obliging the authorities of the Free City of Kraków to ensure that fugitives, deserters or wanted persons belonging to any of these countries would not to find shelter and protection in the city and district of Kraków, and obliging them, upon request, to immediately arrest and surrender such persons under guard. A rigorous approach to this issue also justified a long-term process of reorganisation of the police services and changes to the 'police law', as suggested by the Residents. In this way, the Office of the Mediate Police [Biuro Policji Pośredniej] was transformed into the Police Directorate [Dyrekcja Policji] in 1827. Over time, this body was given more and more competences, in practice gaining wide autonomy in the Free City of Kraków, and all this was done with inspiration and in accordance with the suggestions and "wishes" of the Residents. ${ }^{35}$

It is also worth noting that in September 1837, the Conference of Residents itself amended Articles VII and XI of the Constitution of 1833, which increased the subordination of the Senate to the orders and regulations of the Residents. Also important was the new article introduced to the Constitution, which was unnumbered but was called a supplemental article. As a consequence of these changes, the competences of the Police Directorate in the city of Kraków were further extended and district commissioners were appointed (in place of the former commune administrators ${ }^{36}$ ) ${ }^{37} \mathrm{In} 1837$, the role of the President of the Senate in filling positions in the police and militia services was also expanded $^{38}$.

In 1839, the protecting powers imposed a separate penal code on the Kraków police. They did so in violation of the Constitution, since only after its issuance did they change Article XXVI of the Constitution of 1833 with the additional stipulation that the militia was subject to a separate amendment regarding criminal law. ${ }^{39}$ The code was based on deeply inhumane principles, very severe punishments and the impossibility of appeal in the case of judgements by military courts. This did, however, guarantee the absolute obedience of police officers, who were subordinate to an Austrian commander and thus became an effective tool for the enforcement of strict police regulations in force in the Kraków republic. An additional tool that increased the chances of maintaining the police regime was the judicial reform carried out in 1839-1842, which made the courts

34 P. Cichoń, Dyrekcja..., pp.179-209.

35 This is evidenced by the regulations from 1833 and 1840 regarding the reorganisation of the Police Directorate. Dz. Praw [Journal of Laws] 1834, no. 2736 D.G.S. as well as Dz. Praw [Journal of Laws] 1840, no. 10 D.K.; P. Cichoń, Dyrekcja..., pp. 92-114.

36 Transl. note: wójt (Polish original).

${ }_{37}$ Dz. Praw [Journal of Laws] 1837, no. 5436 D.G.S.

38 Ibidem.

39 W.M. Bartel, Ustrój..., pp. 104-105. 
even more dependent on the executive. Changes in this area were also carried out in accordance with the guidelines of the protecting powers. ${ }^{40}$ In addition, the Conference of Residents mandated a special procedure in case of suspicion of high treason and public offences, abuse of power, theft of public funds, extortion or other betrayal of duties by a senator, president of the court or judge of the Tribunal or Court of Appeal, as well as the director of police. In the case of political offences, investigations were carried out by the Austrian-Prussian-Russian Extraordinary Investigation Commission in the presence of two representatives of the Free City. ${ }^{41}$

The Free City of Kraków met with the domination of its neighbouring states, which were ruthlessly and peremptorily pursuing their goals regarding the destruction of revolutionary movements and the restoration of peace in the region, most strongly after the suppression of the Kraków Uprising. The Conference of Residents of 8 March 1846 required the provisional administration to follow the orders of General Ludwig Collin. A day later, General Collin and General Ivan Panyutin, in accordance with the powers granted by the Residents, appointed the Austrian general, Count Enrico Castiglioni, the temporary head of the military and civil administration of the occupied areas, who was also entrusted with the command of the Kraków garrison. On 22 April 1846, the "Three Majestic Courts" also established the Civil Administration Council of the Free City of Kraków and its Territory [Rada Administracyjna Cywilna Wolnego Miasta Krakowa i Jego Okręgu]. ${ }^{42}$ The chairman had an influence on the personnel chosen for the administration, as he had to give his consent to the appointment and dismissal of officials each time. In addition, he exercised the functions of the "higher police" and "police over foreigners" ${ }^{43} \mathrm{He}$ also issued strict administrative regulations, which increased control over the civilian population. ${ }^{44}$

The geopolitics of the protecting powers concerning collective security, especially in the region of Central and Eastern Europe, has also had a direct impact on the lives of individuals. For example, only with the consent of the Residents, also acting as consuls, was it possible to leave the territory of the Free City of Kraków: via the Russian Resident to France, England, Spain, Portugal, the Netherlands and Switzerland; via the Austrian Resident to Turkey or all of Italy; via the Prussian Resident to all German countries, Sweden and Denmark. ${ }^{45}$

${ }^{40}$ Dz. Praw [Journal of Laws] 1839, no. 23; Dz. Praw [Journal of Laws] 1842, no. 3 D.K.; W.M. Bartel, Ustrój..., p. 93.

${ }^{41}$ The Conference of Residents could also order the investigation of the authorities of the Free City, but at that time the investigation was assisted by delegates of the protecting powers. Moreover, the use of the right of pardon for those convicted of such crimes required the consent of the Residents. W.M. Bartel, Ustrój..., p. 94.

${ }^{42}$ W. Kopff, Wspomnienia z ostatnich lat Rzeczypospolitej Krakowskiej [Recollections of the final years of the Republic of Kraków], seria „Biblioteka Krakowska”, no. 31, Kraków 1906, pp. 95-96; M. Mataniak, Rada Administracyjna Miasta Krakowa i Jego Okręu. Z dziejów XIX-wiecznej administracji krakowskiej [The Administrative Council of the City of Kraków and its Territory: On the history of nineteenth-century Kraków administration], "Studia z Dziejów Państwa i Prawa Polskiego" 2011, Vol. 14, pp. 151-152.

${ }_{43}$ P. Cichoń, Dyrekcja ..., pp. 41-44.

${ }^{44}$ Dz. Rządowy WMK 1846, no. 42-43, s. 168-169; no. 5093; P. Cichoń, Dyrekcja ..., pp. 288-290.

${ }^{45}$ Kalendarzyk polityczny wolnej i niepodległej Rzeczypospolitej Krakowskiej, pod opieka trzech Nayjaśniejszych i Najpotężniejszych Monarchów zostającej, na rok 1834 [Political calendar of the free and in- 
Moreover, the representatives of the partitioning states often asked the Kraków authorities to identify wanted or undesirable individuals who were in the territory of the Free City of Kraków. Among other things, they checked whether the persons indicated by the Residents had taken part in the so-called "Polish Revolution", i.e. the 1830/1831 uprising, or were deserters or conscripts from neighbouring countries. In the case of detained foreigners, at those countries request, they would be expelled from the territory and transferred to the appropriate extradition command post located on the state border (the Russians in Wilczkowice and Michałowice, the Austrians in Podgórze, the Prussians in Chełmek). ${ }^{46}$

Starting in 1833, the Residents also received a daily list of foreigners departing and arriving in Kraków. ${ }^{47}$ They could also raise objections to the issue of emigration passports to people who wished to settle in the Free City of Kraków and obtain citizenship ${ }^{48}$.

Particularly burdensome its effects for a large group of people in Kraków was the demand of the Residents of 9 February 1836, which called on the government to expel within eight days all foreigners, civil and military, who took part in the November Uprising of $1830 / 1831 .{ }^{49}$ Under the pretext of the need to assist the local authorities in this action, in accordance with the decision of the residents, on 17 February 1836 the Austrian army entered Kraków, demanding that the persons who took part in the uprising or could not legitimise their presence in Kraków by presenting a passport or a permit from one of the partitioning states leave the city by 26 February 1836 . This also applied to persons employed in the civil or military service of the Republic, or even those who held citizenship. As a result of this action, several hundred people (about 400-600) were forced to leave Kraków. ${ }^{50}$

To conclude, the Free City of Kraków played a very important role in the regional security policy of the neighbouring states. As a republic created quite accidentally, as a unique experiment that was a political compromise among the three great neighbours, Austria, Prussia and Russia, it was in the constant centre of attention of the partitioning states. The actions taken toward this republic were not improvised, but pragmatically planned and consistently implemented in accordance with the conservative and reactionary policy of these states. The regional cooperation between Austria, Prussia and Russia aimed at stabilizing international relations in this part of Europe and protecting against revolutionary chaos did not hinder the birth and evolution of the idea of Polish national liberation. It did not stop the growing antipathy toward the "protectors", the activities of conspiratorial organizations in the rebellious republic and the maintenance of active contacts with Polish émigrés. At the beginning of the 1840 s, conspiratorial activity grew in strength, and in January 1846 the National Government of the Republic of Poland [Rząd Narodowy Rzeczypospolitej Polskiej] was formed with the dictator Jan

dependent Republic of Kraków, remaining under the protection of the three Most Majestic and Powerful Monarchs, for the year 1834], Kraków 1834, p. 5.

${ }^{46}$ P. Cichoń, Dyrekcja ..., pp. 286-288.

47 Dz. Praw [Journal of Laws] 1834, no. 2736 D.G.S.

${ }^{48}$ P. Cichoń, Dyrekcja ..., pp. 275-276.

${ }^{49}$ Ibidem, pp. 98-100.

${ }^{50}$ J. Bieniarzówna, J.M. Małecki, Kraków..., p. 83; E. Luniński, Zajęcie Rzeczypospolitej Krakowskiej $w$ r. 1836 [The occupation of the Republic of Kraków in 1836], "Przegląd Polski" (Kraków) 1909, Vol. 43, No. 173 , p. 320.

Artykuły - Articles 
Tyssowski at the head, who announced the date of an armed uprising. The uprising, later called the Kraków Uprising, broke out on 20 February 1846, leading to the liberation of Kraków for several days. The fiasco of the uprising determined the fate of the Free City of Kraków - on 6 November 1846, it was incorporated into the Austrian Empire. ${ }^{51}$

It can therefore be concluded that the regional solidarity of Austria, Prussia and Russia and their military dominance in Europe determined the final dismantling of the Free City of Kraków, and that without resulting in any major European diplomatic tensions. Political and legal stability in the region was for a moment secured. The "Vienna Order" could still be saved. Success in this area, however, proved to be very short-lived, for only two years later, in 1848, on a much larger scale, there were further struggles for national liberation across the Habsburg monarchy, known as the "Spring of Nations". That time, the main architect of the Vienna system, Chancellor Klemens von Metternich, also fell. ${ }^{52}$

\section{Bibliography}

\section{Primary sources}

Dz. Praw [Journal of Laws] 1834, no. 2736 D.G.S.

Dz. Praw [Journal of Laws] 1837, no. 5436 D.G.S.

Dz. Praw [Journal of Laws] 1839, no. 23.

Dz. Praw [Journal of Laws] 1840, no. 10 D.K.

Dz. Praw [Journal of Laws] 1842, no. 3 D.K.

Dz. Praw [Journal of Laws] 1843, no. 6 D.G.S.

Dz. Praw [Journal of Laws] 1845, no. 5087 D.G.S.

Dz. Rządowy WMK 1846, no. 42-43, 5093.

Bieniarzówna J., Rzeczpospolita Krakowska 1815-1846. Wybór źródeł [The Republic of Kraków, 1815-1846. Selected sources], seria "Skarby Biblioteki Narodowej", Wrocław-Warszawa 2004.

Kalendarzyk polityczny wolnej i niepodległej Rzeczypospolitej Krakowskiej, pod opieka trzech Nayjaśniejszych i Najpotężniejszych Monarchów zostającej, na rok 1834 [Political calendar of the free and independent Republic of Kraków, remaining under the protection of the three Most Majestic and Powerful Monarchs, for the year 1834], Kraków 1834.

Kallas M., Krzymkowski M., Historia ustroju i prawa w Polsce 1772/1795-1918. Wybór źródet [History of the legal system in Poland 1772/1795-1918. Selected sources], Warszawa 2006.

Królikowski L. (pseud. H. Meciszewski), Memoriat historyczny i polityczny o stanie obecnym Wolnego Miasta Krakowa i jego okregu na poparcie adressu obywateli krakowskich podanego rzadowi francuzkiemu i angielskiemu w październiku 1839 roku z dołaczeniem zbioru dokumentów [Historical and political memoir of the present state of the Free City of Kraków and in support of the address of Kraków citizens submitted to the French and English governments in October 1839, with an appendix of a collection of documents], Paris 1840.

${ }^{51}$ M. Chvojka, Josef..., pp. 311-323, 335-336.

${ }^{52}$ S. Kieniewicz, Polacy ..., pp. 89-93; P.M. Judson, Imperium ..., pp. 164-211; B. Jelavich, The Habsburg Empire..., pp. 50-68.

Artykuły - Articles 


\section{Studies}

Baczkowski M., W cieniu napoleońskich orłów. Rada Municypalna Krakowa 1810-1815 [In the shadow of the Napoleonic eagles: The Municipal Council of Kraków, 1810-1815], Kraków 2010.

Bartel W.M., Ustrój i prawo Wolnego Miasta Krakowa (1815-1846) [The system and the law in the Free City of Kraków (1815-1846)], seria „Biblioteka Krakowska”, no. 116, Kraków 1976.

Bąkowski K., Historya Krakowa w zarysie [Outline of the History of Kraków], seria „Biblioteka Krakowska", no. 6, Kraków 1916.

Beiersdorf O., Kraków wobec powstania listopadowego [Kraków and the November Uprising], Katowice-Kraków 1981.

Bieniarzówna J., Małecki J.M., Kraków w latach 1796-1918 [Kraków 1796-1918], seria „Dzieje Krakowa”, Vol. 3, Kraków 1979.

Cichoń P., Kongres wiedeński a sprawa polska [The Congress of Vienna and the Polish Question] [in:] Idee, normy i instytucje kongresu wiedeńskiego - 200 lat później - perspektywa prawnomiędzynarodowa [Ideas, norms and institutions of the Congress of Vienna - 200 years later - an international legal perspective], Warszawa 2016, pp. 13-25.

Cichoń P., Dyrekcja Policji Wolnego Miasta Krakowa 1827-1846. Studium historyczno-prawne [The Police Directorate of the Free City of Cracow (1827-1846): A Historical and Legal Study], Kraków 2014.

Chvojka M., Josef Graf Sedlnitzky als Präsident der Polizei- und Zensurhofstelle in Wien (18171848). Ein Beitrag zur Geschichte der Staatspolizei in der Habsburgermonarchie [Josef Graf Sedlnitzky as President of the Court Police and Censorship Office in Vienna (1817-1848): A contribution to the history of the state police in the Habsburg Monarchy], series "Schriftenreihe der Internationalen Forschungsstelle «Demokratische Bewegungen in Mitteleuropa 1770-1850»" [Series of the "Democratic Movements in Central Europe 1770-1850" international research centre], Vol. 42, Frankfurt am Main-New York 2010.

Jelavich B., The Habsburg Empire in European Affairs 1814-1918, Hamden, CT 1975.

Judson P.M., Imperium Habsburgów. Wspólnota narodów [The Habsburg Empire. A community of nations], thum. S. Patlewicz, Warszawa 2017.

Kieniewicz S., Polacy wobec traktatu wiedeńskiego [Poles and the Treaty of Vienna] [in:] Europa $i$ świat $w$ epoce restauracji, romantyzmu i rewolucji, 1815-1849 [Europe and the world in the era of restoration, Romanticism and revolution, 1815-1849], ed. W. Zajewski, Warszawa 1991, pp. 66-93.

Kopff W., Wspomnienia z ostatnich lat Rzeczypospolitej Krakowskiej [Recollections of the final years of the Republic of Kraków], seria „Biblioteka Krakowska”, no. 31, Kraków 1906.

Luniński E., Zajęcie Rzeczypospolitej Krakowskiej w r. 1836 [The occupation of the Republic of Kraków in 1836], "Przegląd Polski”" (Kraków) 1909, Vol. 43, No. 173, pp. 310-334.

Małecki J.M., Historia Krakowa dla każdego [A history of Kraków for everyone], Kraków 2008.

Mataniak M., Rada Administracyjna Miasta Krakowa i Jego Okręgu. Z dziejów XIX-wiecznej administracji krakowskiej [The Administrative Council of the City of Kraków and its Territory: On the history of nineteenth-century Kraków administration], "Studia z Dziejów Państwa i Prawa Polskiego" 2011, Vol. 14, pp. 145-171.

Nadziak M.J., Nostalgia za ancien regime'em. Filary europejskiego pokoju 1815-1914 [Nostalgia for the ancien régime: The keystone of European peace], Warszawa 2016.

Pęksa W., Poglady na temat statusu prawno-międzynarodowego Wolnego Miasta Krakowa [Views on the international legal status of the Free city of Kraków], "Krakowskie Studia z Historii Państwa i Prawa" 2008, Vol. 2, pp. 195-206.

Ręgorowicz L., Szkolnictwo W. M. Krakowa w dobie kuratorji Józefa hr. Zatuskiego [Education in

Artykuły - Articles 
the Free City of Kraków at the time of the superintendency of Count Józef Załuski], Warszawa 1930.

Sedivy M., Metternich, the great Powers and the Eastern Question, Pilsen 2013.

Wachholz S., Rzeczpospolita Krakowska. Okres od 1815 do 1830 r. [The Republic of Kraków: 1815-1830], Warszawa 1957.

Wedel-Domaradzka A., Wolne miasta w prawie międzynarodowym [Free cities in international law] [in:] Idee, normy i instytucje kongresu wiedeńskiego - 200 lat później - perspektywa prawnomiędzynarodowa [Ideas, norms and institutions of the Congress of Vienna - 200 years later - an international legal perspective], Warszawa 2016, pp. 451-464.

Winiarski B., Ustrój polityczny ziem polskich w XIX wieku [The political system in Polish lands in the nineteenth century], Poznań 1923. 